\title{
Attosecond angular streaking
}

Doctoral Thesis

Author(s):

Eckle, Petrissa Roberta

Publication date:

2008

Permanent link:

https://doi.org/10.3929/ethz-a-005760979

Rights / license:

In Copyright - Non-Commercial Use Permitted 
ETH Diss. No. 18118

\title{
AtTOSECOND ANGULAR STREAKING
}

A dissertation submitted to

ETH ZURICH

for the degree of

DOCTOR OF NATURAL SCIENCES

\author{
Submitted by \\ Petrissa Roberta ECKLE \\ Dipl.-Phys. (TU München, Germany) \\ born on June 19th, 1979 \\ in Heidelberg, Germany \\ Approved by \\ Prof. Dr. U. Keller, Supervisor \\ Prof. Dr. R. Dörner, Co-Examiner
}

2008 


\section{Abstract}

In this thesis a new technique called 'attosecond angular streaking' (AAS) was applied for the first time. AAS allows to resolve ionization dynamics in the strong field regime with attosecond accuracy $\left(1 a s=10^{-18} s\right)$ using only femtosecond pulses $\left(1 f_{s}=10^{-15} s\right)$. In this regime, ionization mainly proceeds via tunneling through an energetically forbidden barrier.

The process of tunneling is a fundamental and well-understood phenomenon in quantum mechanics. However, attempts to measure the 'tunneling time' have produced controversial results, partly due to the difficulty of defining a temporal operator in quantum mechanics, making it difficult to compare experiments.

In this thesis, the question is addressed of whether the tunneling rate can adjust instantaneously to a changing barrier or if there is a delay $\Delta \tau_{D}$ between the field that defines the barrier and the corresponding tunneling ionization rate. To measure this delay required not only the temporal resolution of the ionization rate but also an independent measurement of the temporal evolution of the electric field with sub-cycle accuracy.

State of the art laser pulses with durations between five to ten femtoseconds easily reach peak electric field strengths comparable to those that bind electrons in an atom. This so-called strong field regime opened the door to phenomena such as high harmonic generation that finally led to the generation of attosecond pulses, to above threshold ionization and tunneling ionization through the potential barrier suppressed by the pulse field. In this regime the interaction of the laser pulse with an atom depends highly nonlinearly on the instantaneous electric field strength of the pulse. The field goes through one oscillation in around 2.5 femtoseconds so that temporal dynamics proceed on a sub-femtosecond timescale. 
AAS is used to resolve these sub-cycle dynamics in time. As soon as an electron is set free through ionization it is accelerated under the influence of the rotating electric field vector of a circularly polarized few-cycle pulse and deflected in its angle. The direction of its final momentum after the pulse has passed then is a direct measure of the instant of ionization: AAS maps time to angle.

In a proof of principle experiment the carrier envelope phase (CEP) of the circularly polarized pulse was measured, demonstrating a temporal accuracy of 23 as and a resolution around 200 as.

To study the temporal dynamics of the tunneling ionization process AAS then was applied in combination with a reference measurement of the electric field. In a static picture the tunneling rate is highest when the barrier is lowest. In the experiment presented here, the circularly polarized pulse modulates the tunneling barrier with the carrier frequency of the pulse so that width and height of the barrier change while the particle is crossing it. This raises the question if the tunneling process leads to a delay between the change of the barrier and the corresponding tunneling rate that could then be interpreted as a 'tunneling delay time'.

The key to measure the time delay between the electric field and the corresponding tunneling rate was to find a 'marker' that is measurable in the field as well as in the ionization rate giving a reference time for both measurements. A slight ellipticity provides this marker by modulating the electric field strength on a sub-cycle time scale. With this method, $\Delta \tau_{D}$ was measured for a range of ellipticities and for various intensities. It was found that indeed, no delay between the electric field and the corresponding tunneling rate exists within an experimental error limit of 12 as. 


\section{Kurzfassung (German)}

In dieser Arbeit wurde attosecond angular streaking (AAS), eine neue Technik, zum ersten Mal angewandt. AAS erlaubt es, unter Verwendung von lediglich Femtosekundenpulsen $\left(1 f s=10^{-15} s\right)$, zeitliche Ionisationsdynamiken im Bereich starker Felder im Attosekundenbereich $\left(1 a s=10^{-18} s\right)$ aufzulösen. Der dominante Ionisationsmechanismus in diesem Starkfeldbereich ist Tunneln durch eine energetisch verbotene Barriere.

Der Tunnelprozess ist ein fundamentales und gut verstandenes quantenmechanischen Phänomen. Versuche, die Tunnelzeit zu messen haben jedoch zu kontroversen Ergebnissen geführt. Dies ist zum Teil durch die Schwierigkeit bedingt, eine quantenmechanische Zeitobservable $\mathrm{zu}$ definieren, was die Vergleichbarkeit von Messungen erschwert.

Die vorliegende Arbeit beschäftigt sich mit der Frage, ob die Tunnelrate sich instantan an eine sich ändernde Barriere anpassen kann oder ob es eine Zeitverzögerung $\Delta \tau_{D}$ zwischen dem Feld, das die Barriere bestimmt und der dazugehörigen Tunnelionisationsrate gibt. Um diese mögliche Zeitverzögerung $\mathrm{zu}$ messen war nicht nur die zeitliche Auflösung der Ionisationsrate notwendig, sondern auch eine unabhängige Messung der zeitlichen Entwicklung des elektrischen Feldes mit einer weit höheren Genauigkeit als einer der Schwingungsperiode des Pulses (sub-cycle).

Laserpulse auf dem aktuellen Stand der Technik mit Pulsdauern zwischen 5 und 10 Femtosekunden erreichen leicht elektrische Feldstärken, die mit den Feldstärken, die Elektronen im Atom binden, vergleichbar sind. Dieser sogenannte Stark-Feld-Bereich eröffnete den Zugang zu Phänomenen wie der Erzeugung höherer Harmonischer, die schliesslich zur Erzeugung von Attosekundenpulsen führte, zur „Above Threshold Ionization“ (ATI) und zur Tunnelionisation durch eine Barriere, die durch das Feld des Pulses unterdrückt wird. In diesem Bereich hängt die Wechselwirkung zwischen 
dem Laserpuls und einem Atom hoch nichtlinear von der momentanen Feldstärke des Pulses ab.

Das elektrische Feld hat eine Periode von ungefähr 2.5 fs, so dass sich die zeitliche Dynamik auf einer sub-Femtosekunden Zeitskala abspielt.

AAS wird verwendet, um diese sub-cycle Dynamik in der Zeit aufzulösen. Sobald ein Elektron durch Ionisation freigesetzt ist, wird es unter dem Einfluss des rotierenden elektrischen Feldvektors eines zirkular polarisierten ultrakurzen Pulses beschleunigt und in seinem Winkel abgelenkt. Die Richtung seines letztendlichen Impulses, nachdem der Laserpuls vorüber ist $t_{\llcorner}$ ist dann eine direktes Mass für den Ionisationszeitpunkt: AAS bildet Zeit auf einen Winkel ab.

In einem ersten Experiment zur Verifikation der Technik wurde die absolute Phase (Carrier Envelope Offset Phase - CEP) des zirkular polarisierten Pulses gemessen; Dabei ergaben sich eine zeitliche Genauigkeit von 23 as und eine Auflösung von etwa 200 as.

AAS wurde dann in Kombination mit einer Referenzmessung des elektrischen Feldes angewandt, um die zeitliche Dynamik des Tunnelionisationsprozesses zu untersuchen.

In einem zeitunabhängigen Bild ist die Tunnelrate am höchsten, wenn die Barriere am niedrigsten ist. In dem hier gezeigten Experiment moduliert der zirkular polarisierte Puls die Tunnelbarriere mit der Zentralfrequenz des Pulses, so dass Breite und Höhe der Barriere sich ändern, während das Teilchen die Barriere durchquert. Dies wirft die Frage auf, ob der Tunnelprozess zu einer Verzögerung zwischen der Änderung der Barriere und der dazugehörigen Tunnelrate führt, die dann als ,TunnelVerzögerungszeit’ interpretiert werden könnte.

Um diese Zeitverzögerung zwischen dem elektrischen Feld und der zugehörigen Tunnelrate zu messen galt es, als Schüssel einen Marker zu finden, der sowohl im elektrischen Feld als auch in der Ionisationsrate messbar ist und so eine zeitliche Referenz für beide Messungen gibt. Ein 
solcher Marker kann durch kleine Elliptizität erzeugt werden, die die elektrische Feldstärke auf einer sub-cycle Zeitskala moduliert. Mit dieser Methode wurde $\Delta \tau_{D}$ für verschiedene Elliptizitäten und Intensitäten gemessen. Das Ergebnis war, dass mit einem oberen Limit von 12 as, bedingt durch die Messungenauigkeit tatsächlich keine Verzögerung zwischen der maximalen Feldstärke und der zugehörigen maximalen Tunnelrate besteht. 